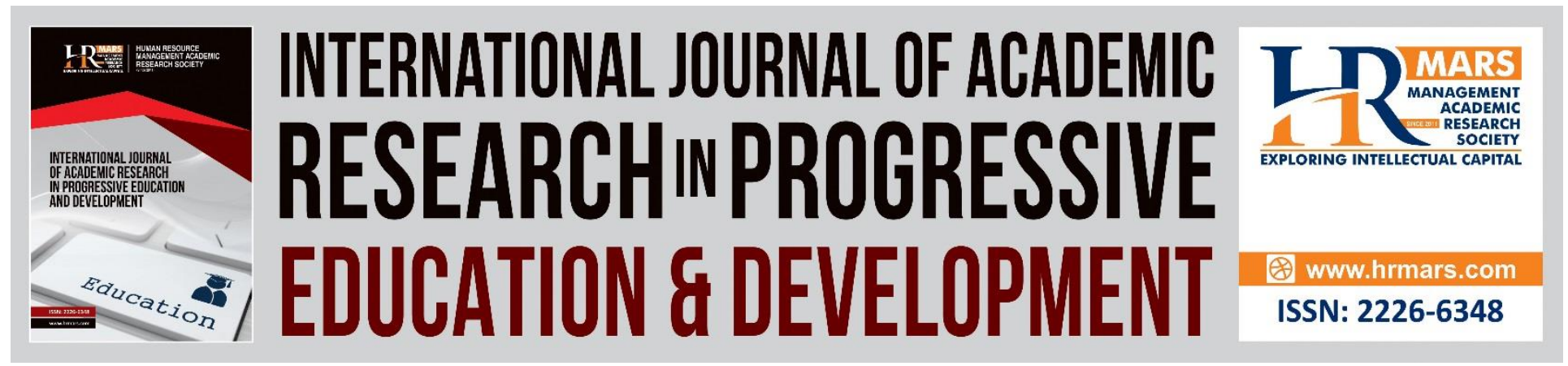

\title{
Exploring Children's Career Planning Through Career Guidance Activities: A Case Study
}

Mohammad Hazim Amir Nordin, Hong Chee Seng

To Link this Article: http://dx.doi.org/10.6007/IJARPED/v10-i2/10071
DOI:10.6007/IJARPED/v10-i2/10071

Received: 01 April 2021, Revised: 26 April 2021, Accepted: 18 May 2021

Published Online: 21 June 2021

In-Text Citation: (Nordin \& Seng, 2021)

To Cite this Article: Nordin, M. H. A., \& Seng, H. C. (2021). Exploring Children's Career Planning Through Career Guidance Activities: A Case Study. International Journal of Academic Research in Progressive Education and Development, 10(2), 754-765.

\footnotetext{
Copyright: (C) 2021 The Author(s)

Published by Human Resource Management Academic Research Society (www.hrmars.com)

This article is published under the Creative Commons Attribution (CC BY 4.0) license. Anyone may reproduce, distribute, translate and create derivative works of this article (for both commercial and non-commercial purposes), subject to full attribution to the original publication and authors. The full terms of this license may be seen at: $\underline{\text { http://creativecommons.org/licences/by/4.0/legalcode }}$
}

Vol. 10(2) 2021, Pg. 754 - 765

\section{http://hrmars.com/index.php/pages/detail/IJARPED}

JOURNAL HOMEPAGE

Full Terms $\&$ Conditions of access and use can be found at http://hrmars.com/index.php/pages/detail/publication-ethics 


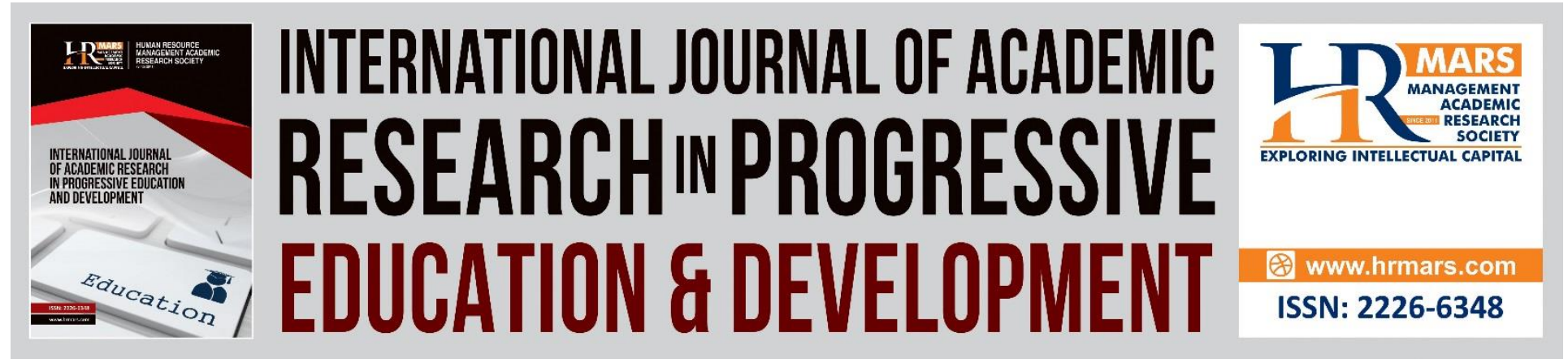

\title{
Exploring Children's Career Planning Through Career Guidance Activities: A Case Study
}

\author{
Mohammad Hazim Amir Nordin
}

Faculty of Education and Human Development Sultan Idris Education University Malaysia

\author{
Hong Chee Seng
}

Faculty of Education and Human Development Sultan Idris Education University Malaysia

\begin{abstract}
Researchers should widen their exploration of career planning through career guidance activities among children. Studies and researches have been done linked to career planning from childhood will have an impact on their career choices in future. This study aimed to explore the impact of career planning by children through their career guidance activities. This study is conducted on 12 -year-old children who have issues with their career planning process. The findings show that there are four themes that have been successfully identified, namely the understanding of career, sources of career information disclosure, career choice and understanding of employment through parents' occupation.

Keywords: Exploration, Children, Career, Guidance, Planning

\section{Introduction}

In general, career planning is an individual process in making self -assessment, evaluation of career opportunities and action planning correlated to their career objectives. All in one, the starting point in this career selection process is to start since one is still a child and is in school. The process of planning and choosing the right career is able to determine the pattern of a person's life in the future and it will have an impact on the well-being of their lives.

\section{Children's Career Guidance}

Career guidance to children refers to a process given systematically and continuously in order to form competencies and attitudes towards career planning, higher levels of learning (flow breakdown), adaption to the environment or any progress towards planning, selection and career. Kashefpakdal, Rehill \& Hughes (2018) explained that career development is a maturation process towards life management, learning and world of employment. The process of children's career guidance is more focused on early career exposures that can be developed through knowledge and skills; integrated through teaching and learning or through non-academic
\end{abstract}


programs such as career counselling, clubs and associations or entrepreneurship programs, leadership programs and etc. Therefore, career planning is seen as an important thing for children because it can not only help increases their motivation to achieve what desires them the most and ambitions, but with the existence of career planning, it can provide early awareness to children to make their own career choices and further strategies for their life goals.

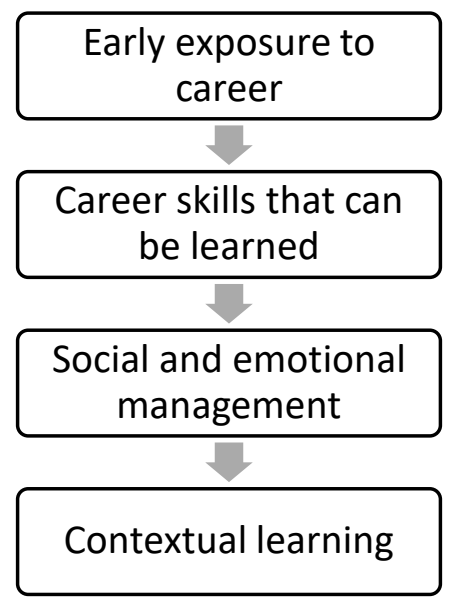

Figure 1: Scope of child career guidance application.

Figure 1 explains scope that can be applied during the process of children's career guidance; an early exposure to the career, career skills that can be learned, social and emotional management and contextual learning. For children, thinking about a career is a long-term plan because of the age factor, there are still a long way for them to reach the working age. However, it is not a barrier for them to recognize and understand jobs field available based on the socio environment or outside their environment. The initial exposure that can be given to children is to identify types of jobs, understand field of work, exposed to role of the job in the community, or gain experience directly or indirectly in any field of work. In coaching process, approaches that can be used are gamification, competitions, interview their chosen career icons, role-playing activities, acting and others. This early exposure is able to shape children's inclinations and interests towards the choice of a career as an ambition. Meaning that the influence of the environment through this early exposure does not limit children's career choices based on people who are significant to themselves alone.

Next, career skills that can be learned. For example, entrepreneurial skills, leadership skills, problem solving skills, communication skills and other skills that are considered necessary. All of these job skills are also an early exposure in preparing children towards the process of their career planning and selection. Child's attitude can be formed so that it can be an encouragement and motivation to children in achieving their ambitions. Approaches that can be used to transmit children's early knowledge and experience are through activities suggested such as experimental learning activities and project-based activities. In addition, exposure to social and emotional management is also an important element in career guidance. This is because, social 
management is a method for children to learn and master their socialization skills and at the same time make them understand how social structures and systems work. As for emotional management, it aims to help children to make good judgments and be selective on their career planning. This to ensure they are able to prepare their emotions in good condition and under control if what has been planned is unachievable. It can be seen the implications for children are so that they can train themselves rational and positive thinking in achieving their ambitions. Contextual learning refers to programs or activities conducted either in teaching and learning or non-academically where students are given direct exposure and experience through series of sharing with successful individuals in their careers. This will enable children to see the world of work in their own scope. The experience and knowledge shared can be used as a guidance in the career planning and selection process.

\section{Children's Career Planning}

Career planning is a process a person goes through to determine a lifelong work plan. Career planning also refers to the assessment of abilities and interests, take into consideration of career choices and opportunities, formulating career goals and practical planning of development activities. Career planning is also a process of a person choosing their career goals and trying to achieve those goals (Brown, 2003; Wether \& Davis, 1996). Findings show that orderly, effective career planning and management is important for an individual. This is because, the main emphasis in this process is goal setting which shows that the individual has a clear vision of the future and provides a satisfying target in performing the task (Greenhaus, Callanan \& Kaplan (1995). Career planning is one of the phases that need to be passed in life towards maturity and it is a process to increase the chances of getting a job that fits one's career goals (Kosine \& Lewis, 2008). Career planning phase is different for each individual. This phase shows some personal factors that constantly change the experience of an individual.

These personal factors in turn will have an impact on the formation of individual career interests whether it is successful or unsuccessful in making one's future career plans systematically. One out many personal factors of career planning for children is personality. Differences in personality structure cause a person to form certain needs that can only be met through job choices (Teevan, 1954). One of the major studies on personality is the division on personality dimensions by Barrick \& Mount, (1993) namely the Big Five. They have studied the relationship between personality dimensions which has been divided into five main dimensions.

The first five main dimensions are extrovert (extraversion) which includes social, talkative and assertive. Next, agreeableness it is a good attitude, cooperation and trust. Third, conscientiousness which is responsible, dependent, persistent and achievement oriented. Fourth, emotional stability and last but not least is openness to experience, which is imaginative, artistically sensitive and intellectual. The personality inventory introduced by a local researcher, the Sidek Personality Test (Noah, 2001), is a combination of western researchers who focus their research on aspects of career interests, namely John L. Holland. What is interesting about this Sidek Personality Test is that it has broken down or divided the large personality dimensions in the Big Five into smaller traits. The fifteen personality traits are aggressive, analytical, 
autonomous, lean, extrovert, intellectual, introvert, diversity, resilience, self-criticism, controlling, helping, supportive, structural and achievement.

The next factor is interest. Interest propensity is important in career planning because individuals which involved in a particular occupation tend to like or dislike certain things in the occupation and this is what distinguishes them from other individuals in other occupational groups as well as the general public (Shertzer \& Stone, 1981). According to Strong, (1955) a person's interest changes quite a lot between the age of fifteen and twenty years old where they become more stable and does not change much. Most of the changes that occur upon maturity will decrease at the age of twenty years old and become more systematic based on interest inventory data. Super (1980), has made four interpretations on the term of interest.

Super Interpretation can be summarized as follows. Firstly, individuals who can expressed verbally towards an object, task or occupation. The person can state thing that they like or dislikes and indifference towards their occupations. The second manifested interest is the involvement in occupation. Objective of the manifestation on interest is studied to avoid the subjective state of a statement. The third interest refers to interest that measured by objective testing and which differs from inventory based on subjectively self-estimation. It is assumed that interest in a job is often demonstrated through action and it should result in a collection of relevant information and the fourth is an inventory of interests, which refers to the evaluation of one's main choices of various occupations.

The next factor is talent. A person's performance in a career field is influenced by a combination of various special talents or abilities. Each job has different needs in terms of specific talents. The requirements in terms of quality and competencies required in a job are also different. Any type of job usually requires some competency and identified as an early requirement (Shertzer \& Stone, 1981). A person's talent influences the level of work one's may achieve, the training one's may enter and the quality of work one's able to do. However, one's talent has no equal affinity with all of these possibilities. As noted earlier, special talents are more related to success in training than to success in job performance. This is probably because success in job performance is based on a broader set of expectations and criteria than success in training. According to Super (1957), humans differ in terms of abilities, interests and personalities. Therefore, they are eligible to enter various types of jobs. This is because, every job has a specific pattern that can accommodate a wide variety of people in each job.

In fact, motivation is also one of the contributing factors to the career selection process. Each individual has different aspirations, backgrounds and different experiences (Walker, 1980). This can be seen in terms of individual personalities that can be formed through interaction with different environments. Based on the research that has been done by Edger Schein (Walker, 1980) there are five motivational differences that influence an individual's career planning. Among them is management competence. The career goal for managers is to shape the quality of interpersonal, analytical and emotional competence of employees. Individuals who use this motivation have a goal to encourage others. 
Vol. 10, No. 2, 2021, E-ISSN: 2226-6348 @ 2021 HRMARS

Next to technical or functional competence i.e. motivation for technical function is the continuous development of technical talent. These individuals will not stress on the aspect of self -development in the field of management. One out of the others is safety where individuals who prioritize this motivation are very concerned about a stable work situation. Usually they will see themselves as close or well-integrated with the organization. Next is creativity where creative individuals will always try to explore or they will create something to get outcomes from the achievement of their goals. While the latter is autonomy and fortune where it refers to individuals who love freedom and have the desire to work free from organizational barriers and restrictions. This causes individuals tend to be leaders and self-employed.

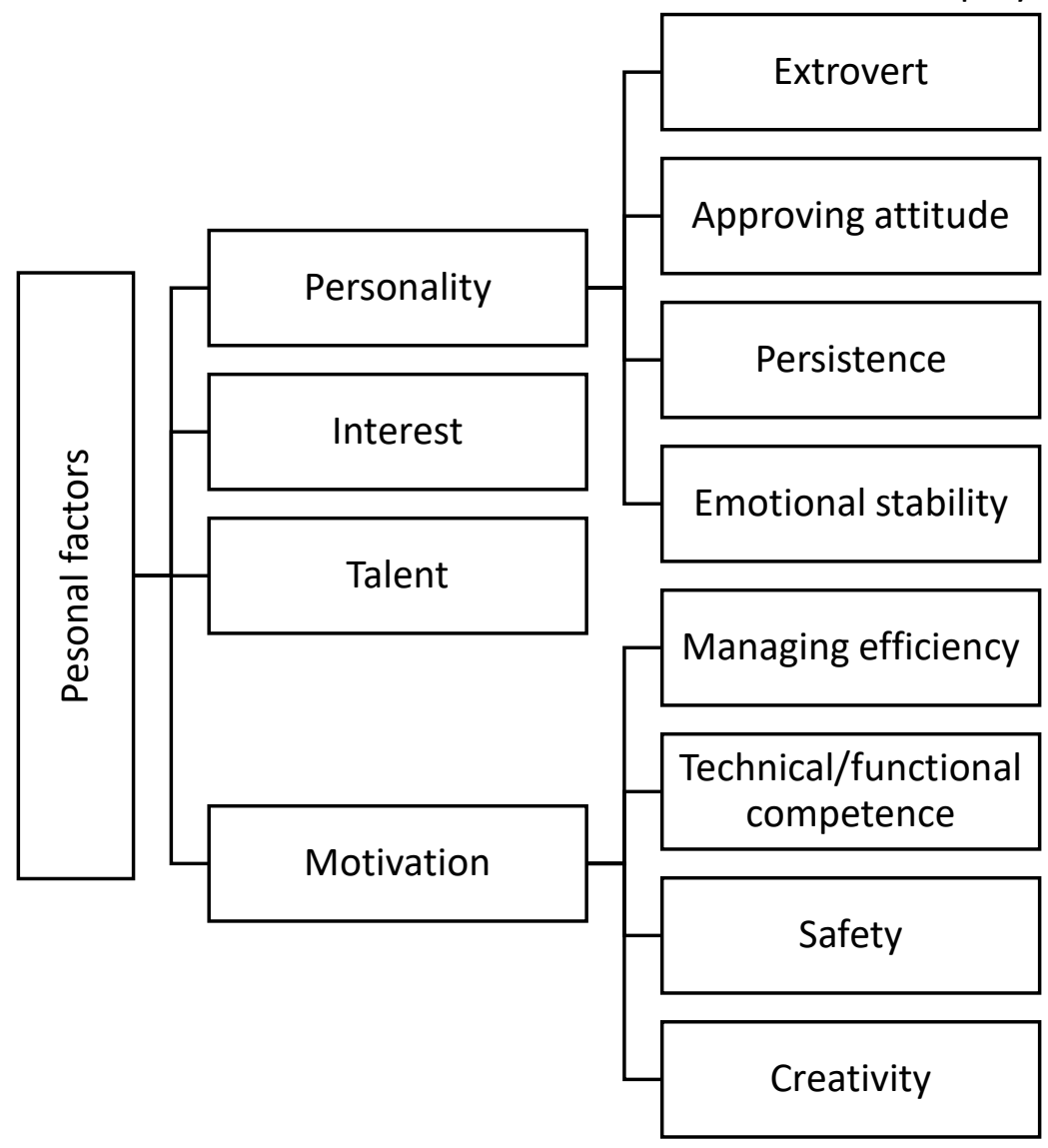

Figure 2. Barrick and Mount Children's career planning factors, Seng (2020).

\section{Children's Career Planning Process}

There are four stages of the career planning process through the career and academic planning model (academic career plan model); to know, explore, plan and carry out planning (Evers, 2017). Knowing refers to self -awareness where the individual needs to make an assessment of self-interests and strengths, make self -reflection and goal setting, understand and have knowledge of financial and resource management aspects, master academic skills and preparatory skills and lastly understand types of behavior and master career preparation skills. Exploring aspect is to explore the activities and learning syllabus at a higher level, explore the world of careers and the needs of the market, make comparisons on career skills training at the 
secondary school level. The next aspect is planning where individuals are required to master planning skills, started planning at the lower secondary, upper secondary and university levels. Finally is career management which is to run a planning plan, keep the plan updated with new information, attend seminars and mentoring programs.

As for children, career planning process does not involve direct career choice as what happens to adults. Children's need for family planning involves planning in academics and their early exposure towards what type of career interests them the most. This academic and career development provides space and opportunities for children to make self-exploration, career exploration and form mastery of career development and planning skills. While at primary or lower secondary school level, children are able to develop career potential and talents through the formation of attitudes and habits in a productive way of learning. They can also increase their self-confidence and at the same time give them prospect to learn in decision making. In child career development model (Super, 1990) there are nine concepts highlighted as shown in the figure below.

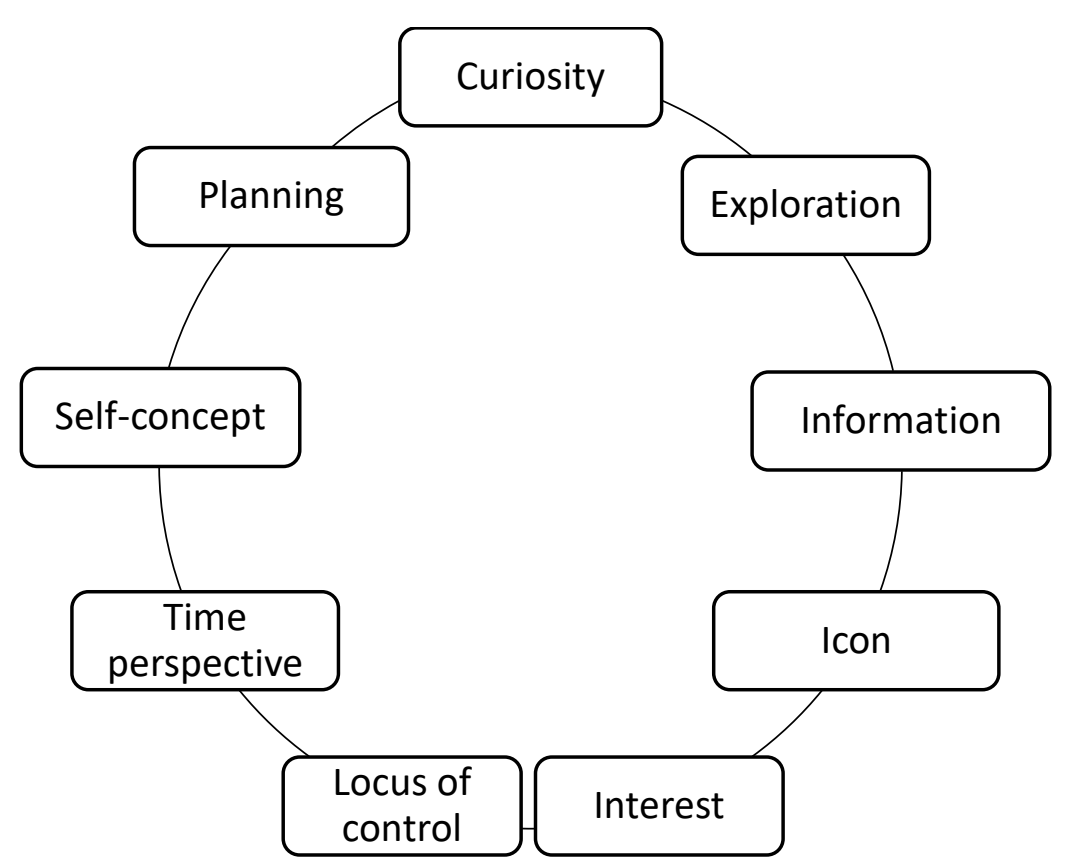

Figure 3. Child career development model (Super, 1990).

Through nine concepts introduced by Super 1990 in figure 3, curiosity refers to a child's exploratory power to study, learn and wonder. Exploration is the act of gathering information about the environment and meeting the satisfaction needs of exploration. Children explore their environment, home, school and etc. Next, the information which children are capable of having awareness and realize the importance of career-related information. While icon is a role model, an individual who has a significant relationship with children in providing them exposure to the world of career and the concept of personality. Interest, on the other hand, refers to things that child is interested in or not interested in. Next, the locus of control where it occurs to children gradually. Time perspective refers to a child's ability to see the past, present and future in terms 
of future career planning. In addition, the concept of self in the nine concepts shows the individual dimension in exploring a particular situation or certain circumstances. Finally, planning which is clear planning and to help children in making their decisions.

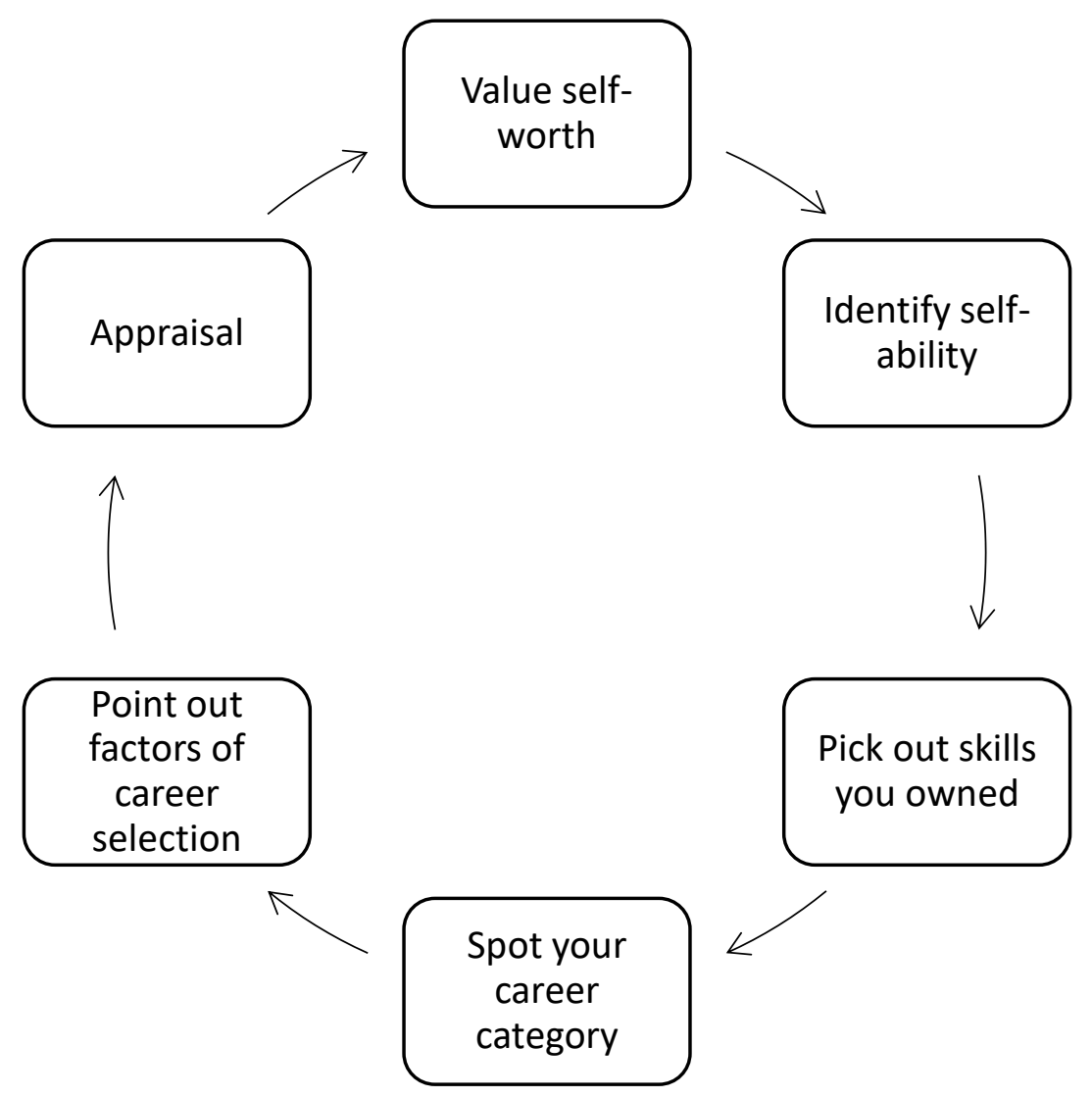

Figure 4. Children's career planning process.

Figure 4 explains some of the career planning processes that can be applied to children. The first is to value self-worth. Children are guided to recognize their self-worth that leads towards appropriate career choice. Next, identify their self-ability. Children are guided to identify their own strengths and weaknesses so that they can make a connection with the type of career chosen by them. Besides that, children are also will be guided to pick out skills they owned or mastered because the tendency of interest in career choice is based on the skills they have. The next step is students are guided to spot their career category and point out factors of their career selection based on their skills and abilities. This is to ensure their career choice is applicable and does not burden the child. Lastly is to make an appraisal through processing the experiences and perspectives of children and adults. 
DEVELOPMENT

Vol. 10, No. 2, 2021, E-ISSN: 2226-6348 @ 2021 HRMARS

\section{Sample of Study}

Sample study consisted of a 12-year-old boy, currently attending a government school in Kuala Lumpur and experiencing issues in his career planning process. Participant is a student who come from modest socio-economic demographics, Malay ethnic and candidate of an excellent student in his school.

\section{Findings and Discussion of Study}

The researcher was able to conclude that there are four main themes that can be found through discussion and comparison between participant's dialogue transcription and his structured coding book.

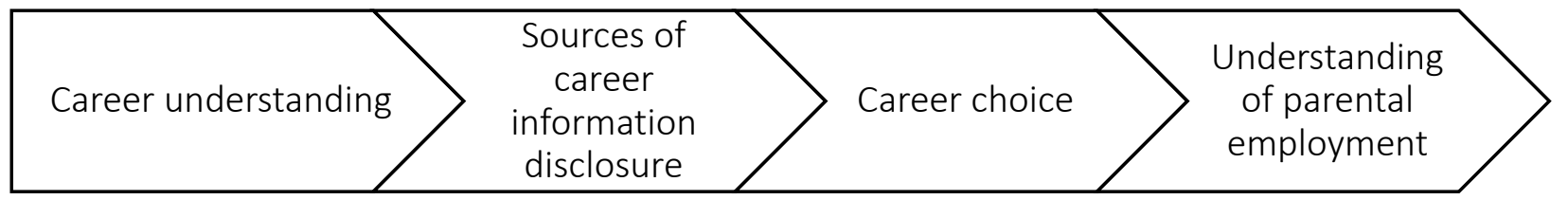

Figure 5. Superordinate themes of career awareness, four main themes of the study.

Researchers found that career awareness was the first element in influencing children's early career planning followed by themes that included career understanding, sources of career information disclosure, career choice and understanding of parental employment. These side of elements are also among the contributing factors for students get to know career world and begin to make their career choices through their imagination. Next, the importance of career planning is a second major theme which students begin to expose towards the awareness gathering early carrier planning experience in reality. Therefore, steps in career planning are third superordinate theme found when there are similarities in the implementation of respondents' respective strategies to succeed in their initial career planning. Finally, the researchers were also able to identify fourth superordinate theme which he also faced some trials in career planning and there are variances in handling their challenges in real world.

Researchers are also able to pinpoint the perspectives of study participants by showing the concept of career as their job option in the future and a dream that can be achieved. For example, study participants stated that: "Uh... to me the word career means... what career will I choose in the future. Uh... work". But on the other hand, the knowledge of participants about popular jobs nowadays is very limited. Lack of exposure to the latest career trends in its environment is one of the reasons why. Through interviews, researchers also have the opportunity to explore participant's disclosure information of career. He has collected career information through observations based on his daily life where he obtains information related to his family members' career and observes their work routines. Thus, it can be seen that the participant is able to access information better on type of work which is related to his life through his parents or input that is conveyed indirectly from the media. 
In line with his existing career knowledge, he is also able to make career choices at an early stage of his career development. It is proven when he has expressed his desire "I want to become a lawyer" during his interviews. This show that children are starting to build career awareness fundamentally. Factors influencing the career choice of participant can also be detected from media, self-interest, parental advice based on their career experience, and his ambitions since childhood. Participant had advocacy as a lawyer through drama viewing. He tends to make his own career exploration through the various aspects. In addition, interview indicators indicated that participant lacks of his understanding towards the importance of career planning or the opposite. The statement of the study findings can be explained by his stands towards career planning. However, his lack of understanding towards the importance of career planning clearly can be seen through his response when he shook his head as a sign of misunderstanding after researchers asked about the topic.

Researchers also discovered that participant adhere to his self-principle; not easily to give up and strive to achieve his life goals. Having a clear direction and high self-confidence is a driving factor in career planning. It can be seen through the interview "You have to work hard, then you will earn it." "It gave me a lesson to uh..try and we will get what we want". Furthermore, parents' characteristic plays a dominant role in giving influence and encouragement to participants in doing his career planning. In his early stages, he is lacked of understanding in knowing the purpose and steps in designing his career. He usually receives a lot of mental and physical support from his parents. This can be seen through his sharing during the interview "Umm, my mom is a teacher, so she has been educating me since childhood and she has told me to achieve something, we have to work for it". For further action in his implementation of career planning, participant will set the academic path to his dream secondary school or follows his career figures' step who achieve success in life and it can be seen through his interviews with researchers "My target is to get 6 A's and I want to enter MRSM".

\section{Conclusion}

In the nutshell, it is proven that career planning process does not only occur during the early stages of adolescence. It also should be applied to children so that the process of planning their career happened well in the future. In addition, other than taking responsibility for academic learning and personal development, career planning is also one of the obstacles that children face; considering the early selection of suitable career would give big impact on the development of a person's life long journey. Further research can be done to explore more about children career planning and career decision.

\section{Authors Contribution}

Mohammad Hazim Amir Nordin and Hong Chee Seng contributed to the development of the contextual, theoretical and study design. Hong Chee Seng performed the data analysis whilst Mohammad Hazim Amir Nordin drafted the manuscript and made the critical revisions in the study. Authors had discussed the results, implications, literature and approved the final version of the manuscript for submission. 
INTERNATIONAL JOURNAL OF ACADEMIC RESEARCH IN PROGRESSIVE EDUCATION AND

DEVELOPMENT

Vol. 10, No. 2, 2021, E-ISSN: 2226-6348 @ 2021 HRMARS

\section{Acknowledgement}

Acknowledgement to Associate Prof. Dr. Noraini Ismail and Dr. Pau Kee from Faculty of Education and Human Development Sultan Idris Education University for the splendid advice and also Mrs. Noraitah Marusin and Mrs Adila Arifah Abdul Hadi for the valuable discussion and opinion in this study.

\section{Corresponding Author}

Mohammad Hazim Amir Nordin

Faculty of Education and Human Development, Sultan Idris Education University, Malaysia.

Email: mohammad_hazim@yahoo.com

\section{Reference}

Barrick, M. R., \& Mount, M. K. (1993). Autonomy as a moderator of the relationships between the big five personality dimensions and job performance. Journal of Applied Psychology, 78, 111-118.

Brown, D. (2003). Career information, career counselling, and career development (8th ed.). Boston: Pearson Education.

Evers, T. (2017). Implementing academic and career planning. USA: Wisconsin Department of Public Instruction.

Greenhaus, J. H., Callanan, G. A., \& Kaplan, E. (1995). The role of goal setting in Career management. International Journal of Management. 7(5). 3-12.

Kashefpakdal, E., Rehill, J., \& Hughes, D. (2018). What work? career-related learning in primary school. United Kingdom: Career \& Enterprise Company.

Kosine, N. R., \& Lewis, M. V. (2008). Growth and exploration: Career development theory and program of study. Career and Technical Education Research. 33(3), 227-243.

Seng, H. C. (2020). Fenomenologi tentang pengalaman awal murid tahun enam dalammembuat perancangan kerjaya. [Unpublished Master's Thesis]. Universiti Pendidikan Sultan Idris.

Shertzer, B., \& Stone, S. C. (1981). Fundamentals of guidance (4th ed.). Boston: Houghton Mifflin.

Noah, S. M. (2001). Perkembangan kerjaya teori dan praktis. Serdang: Universiti Putra Malaysia.

Strong, E. K. (1955). Vocational interests 18 years after college. Minneapolis: University of Minnesota Press.

Super, D. E. (1957). The psychology of careers; an introduction to vocational development. New York: Harper \& Bros.

Super, D. E. (1980). A life span, life space approach to career development. Journal of Vocational Behaviour. 16(3), 282-298.

Super, D. E. (1990). A life-span, life-space approach to career development. In D.

Brown \& L. Brooks, Career choice and development: Applying contemporary theories to practice (pp. 197-261). Jossey-Bass.

Teevan, R. C. (1954). Personality correlates of undergraduate field of specialization. Journal of Consulting Psychology, 18(3), 212-214.

Walker, J. W. (1980). Human resource planning. New York: McGraw-Hill. 
INTERNATIONAL JOURNAL OF ACADEMIC RESEARCH IN PROGRESSIVE EDUCATION AND

DEVELOPMENT

Vol. 10, No. 2, 2021, E-ISSN: 2226-6348 @ 2021 HRMARS

Werther, J., \& Davis, K. (1996). Human resources and personnel management. $5^{\text {th }}$ Edition. New York: McGraw-Hill. 